\title{
Triticum mosaic virus Isolates in the Southern Great Plains
}

Irazema Fuentes-Bueno, USDA-ARS, Hard Winter Wheat Genetics Research Unit, 4008 Throckmorton Hall, Manhattan, KS 66506; Jacob A. Price and Charles M. Rush, Texas AgriLife Research, 2301 Experiment Station Rd., Bushland, TX 79012; Dallas L. Seifers, Agriculture Research Center, Kansas State University, Hays, KS 67601; and John P. Fellers, USDA-ARS, Hard Winter Wheat Genetics Research Unit, 4008 Throckmorton Hall, Manhattan, KS 66506

\begin{abstract}
Fuentes-Bueno, I., Price, J. A., Rush, C. M., Seifers, D. L., and Fellers, J. P. 2011. Triticum mosaic virus isolates in the southern Great Plains. Plant Dis. 95:1516-1519.

In 2006, a previously unknown wheat (Triticum aestivum) virus was discovered in Western Kansas and given the name Triticum mosaic virus (TriMV). TriMV has since been found in wheat samples isolated all across the Great Plains. Even though it can infect singularly, TriMV is mostly found with Wheat streak mosaic virus (WSMV) as a co-infection. The potential for TriMV to cause economic loss is significant, but very little is known about the virus. The objective of this study was to survey the TriMV population for genetic variation by nucleotide sequencing of isolates across a geographical region. A secondary objective was to characterize the WSMV isolates that are being co-trans-

mitted with TriMV. Fourteen different TriMV isolations were taken from locations in Texas, Oklahoma, and Kansas, and the coat protein cDNA was sequenced. Thirteen nucleotide differences were found in the TriMV isolates, of which three induce amino acid changes. WSMV isolates had 65 nucleotide changes when compared to WSMV Sydney81. Our results indicate the TriMV virus population has minimal amounts of sequence variation and no singular WSMV genotype is specifically associated with TriMV co-infection. Based on the isolates analyzed, it appears that the field population of TriMV is very homogeneous.
\end{abstract}

Triticum mosaic virus (TriMV) is a recently discovered virus first isolated in 2006 from a research plot of winter wheat cultivar RonL (Triticum aestivum L.; 15). Plants within the plot were expressing mosaic-like symptoms similar to those caused by Wheat streak mosaic virus (WSMV); however, antigen tests indicated symptoms could not be attributed to WSMV or other known wheat viruses $(15,16)$. Kansas TriMV isolate 06-123 (3) and a Nebraska isolate (25) have been sequenced, and the genomes indicate TriMV is most closely related to Sugarcane streak mosaic virus (SCSMV), a member of the family Potyviridae, and is only 40\% identical to other wheat-infecting potyvirids, including WSMV (3), the type virus for the Tritimovirus genus. Virion morphology and sequence alignments suggest TriMV belongs to the family Potyviridae and did not originate as a recombinant of or selection from another viral population $(3,25)$.

TriMV is transmitted by the wheat curl mite (WCM), Aceria tosichella Keifer (14), the same vector for WSMV (20) and High Plains virus (HPV, 11; also known as Maize red stripe virus (19), although neither has been approved by the International Committee on Taxonomy of Viruses). Both TriMV and WSMV can be transmitted singly or together by WCM, and the transmission efficiency of TriMV is higher when WSMV is present (14). When coinfected, both viruses will replicate at different rates. Tatineni et al.

Corresponding author: John P. Fellers, E-mail: john.fellers@ars.usda.gov

This is a joint submission of the U.S. Department of Agriculture and the Kansas Agricultural Experiment Station. Contribution number: 11-260-J.

Mention of a trademark of a proprietary product does not constitute a guarantee of warranty of the product by the United States Department of Agriculture and does not imply its approval to the exclusion of other products that may also be suitable. USDA is an equal opportunity provider and employer.

Accepted for publication 5 July 2011.

doi:10.1094/PDIS-04-11-0281

This article is in the public domain and not copyrightable. It may be freely reprinted with customary crediting of the source. The American Phytopathological Society, 2011.
(24) have shown WSMV accumulates at a higher rate after initial co-infection, but TriMV surpasses WSMV in titer at later stages of infection. The host range of TriMV includes the crop species barley, oats, rye, and triticale $(12,24)$ and includes native grass species Aegilops cylindrica, Avena fatua, Bromus arvenis, B. secalinus, B. tectorum, Eriochloa acuminata, E. contracta, and Setaria viridis, which are found in wheat growing areas of the Great Plains (12). TriMV infection can cause significant reductions in wheat yield and volume weight, but the effect may be cultivar specific (13).

In 2008, the Great Plains Diagnostic Network (GPDN) conducted a survey to determine the distribution of five wheat viruses. Wheat samples were collected throughout the region and sent to state plant disease diagnostic laboratories. TriMV was found singly infected in $17 \%$ of the samples from seven states. The study also found TriMV and WSMV co-infected in $13 \%$ of the samples (1). Results indicated that TriMV is widespread and may have been present for some time, although not detected until recently. In collaboration with the Texas AgriLife Plant Pathogen Diagnostic lab, we set out to determine the genetic diversity of TriMV. The objective of this work was to use cDNA sequencing of the coat protein (CP) of TriMV to determine the virus variability. A second objective was to determine if there was isolate specificity of WSMV that co-infected with TriMV.

\section{Materials and Methods}

Isolates from two different collections were used in this study. The first consisted of plant material collected in 2008 by producers, laboratory technicians, and extension personnel involved in the GPDN (1). Samples from Texas, Kansas, and Oklahoma were submitted to respective plant pathology diagnostic laboratories and tested for the presence of TriMV, WSMV, HPV, Barley yellow dwarf virus-PAV (BYDV-PAV), and Barley yellow dwarf virusRPV (BYDV-RPV) by enzyme-linked immunosorbent assay (ELISA; Agdia Inc.). Samples testing positive for TriMV were frozen and sent to the Texas AgriLife Research Center, Plant Pathology Diagnostics Laboratory in Amarillo, TX, from which nine were selected for this study based on geographic distribution. The nine isolate designations and the counties of collection are listed in Table 1 and highlighted in blue in Figure 1.

The second group of TriMV isolates was collected in 2006 soon after the discovery of TriMV (15) and maintained by monthly cy- 
cles of reinfection onto seedlings until leaf tissue was collected in 2008. Six isolates were collected from naturally infected wheat in Kansas counties: Pawnee (KS-76-PA), Ellis (KS-123-EL), Thomas (KS-149-Th), Ford (KS-153-Fo), Ness (KS-161-Ns), and Osborne (KS-337-Os) (Fig. 1, highlighted in yellow). Wheat samples were analyzed by ELISA using antiserum raised to WSMV CP (10) and HPV (18). A portion of each wheat sample was frozen and later analyzed by ELISA once antibodies were raised to TriMV (15). Each isolate was maintained in the wheat cultivar Tomahawk by mechanical (finger-rub) inoculation with 1:10 wt/vol of tissue in $0.02 \mathrm{M}$ sodium phosphate buffer, $\mathrm{pH} 7.2$, from a given sample as described previously (17). Once the isolates were transferred to Tomahawk, they were again analyzed by ELISA for contaminating infection with WSMV. Isolates were reinoculated onto new plants every month for 20 months.

RNA isolation and cDNA construction. For the first collection, total RNA was extracted from 0.08 to $0.1 \mathrm{~g}$ of tissue using the RNeasy Plant RNA extraction kit (Qiagen) according to the protocol. Tissue was homogenized with liquid nitrogen and added to $450 \mu \mathrm{l}$ of RLT buffer, transferred to the provided QIA-shredder column, and centrifuged at $15,000 \times g$ in a microcentrifuge (Beckman) at room temperature. The flow-through was mixed with 225 $\mu \mathrm{l}$ of $100 \%$ ethanol, added to the RNeasy spin column with $700 \mu \mathrm{l}$ of RW1 Buffer, and centrifuged as before. After two washes of 500 $\mu \mathrm{l}$ of RPE buffer, the spin column was transferred to a new $1.5-\mathrm{ml}$ microcentrifuge tube. Total RNA was eluted from the spin column using two washes of $20 \mu \mathrm{l}$ of RNase-free water heated to $65^{\circ} \mathrm{C}$. For the second collection of isolates, $100 \mu \mathrm{g}$ of purified virus was used for RNA extraction, and the procedure was followed as above with the addition of $450 \mu \mathrm{l}$ of RLT buffer to the virus solution. Reverse transcription (RT) was used to construct cDNA template for amplification. RT reactions consisted of $100 \mathrm{ng}$ of total RNA, $1 \mu \mathrm{l}$ of $10 \mathrm{mM}$ dNTPs, 50 pmoles of oligo d(T) $)_{18}$ primer, $4 \mu \mathrm{l}$ of $5 \times$ firststrand buffer (Invitrogen), $2 \mu \mathrm{l}$ of $0.1 \mathrm{M}$ DTT, and $1 \mu \mathrm{l}$ of Superscript II RT (Invitrogen). Reactions were incubated in a heat block at $42^{\circ} \mathrm{C}$ for $1 \mathrm{~h}$ followed by $72^{\circ} \mathrm{C}$ for $15 \mathrm{~min}$.

Polymerase chain reaction (PCR) amplification, cloning, and sequence analysis. Primers for PCR amplification of the CP sequences of TriMV (region 9196-10077 of the complete genome FJ263671; 15) and WSMV isolate Sidney 81 (region 8361-9097 of the complete genome AF057533; 21) were designed using MacVector v10.6 (MacVector, Inc.). TriMV primers were: forward 5'AATCTGGTGTTGTTAAGGATC- $3^{\prime}$ and reverse $5^{\prime}$-GACACG TGTACGACCATAA-3'. WSMV CP primers were: forward $5^{\prime}$ CACAAACACAATCTAATAACG- $3^{\prime}$ and reverse 5'-ACTGCA ACGCTGTTCTG-3'.

The PCR reactions included $1 \mu \mathrm{l}$ of the RT product, 10 pmoles of forward and reverse primer, $1 \times$ final concentration Taq polymerase buffer (Sigma-Aldrich), $10 \mathrm{mM}$ dNTPs, and 0.25 units of Taq polymerase (Sigma-Aldrich). Products were amplified using a PTC-200 MJ Research thermocycler (MJ Research) with 35 cycles of $92^{\circ} \mathrm{C}$ denaturation for $1 \mathrm{~min}$, annealing of $55^{\circ} \mathrm{C}$ for $2 \mathrm{~min}$, and an extension of $2 \mathrm{~min}$ at $72^{\circ} \mathrm{C}$. PCR fragments were cloned into pCR2.1 (Invitrogen), and plasmids were purified according to the protocol using Qiagen Spin Miniprep Kit. Clones were sequenced using Big-Dye v 1.1 terminator chemistry (Applied Biosystems) at the Kansas State University Sequencing facility on an ABI 3730s DNA Analyzer. DNA sequence and alignments were analyzed using MacVector v11.0.4 and MacVector Assembler (MacVector Inc). Sequence alignment comparisons used the ClustalW function of MacVector with the settings of BLOSUM series, open gap penalty of 10 , extend gap penalty of 0.2 , and delay divergent of $30 \%$.

\section{Results}

Isolates from collections. The first collection of isolates represented a diverse and widespread area of wheat cultivation and came from three counties in Texas: Oldham, Ochiltree, and Hale; three counties in Oklahoma: Washington, Kingfisher, and Texas; and three counties in Kansas: Smith, Thomas, and Meade (shaded blue, Fig. 1). All were tested by ELISA for the presence of TriMV, WSMV, and HPV; and the Oklahoma and Texas samples were tested for two species of Barley yellow dwarf virus (BYDV). TriMV was found in all of the samples (Table 1). Seven of the samples contained antigens for WSMV, while samples 24 from Oklahoma and 44 from Kansas did not. Sample 50 from Oklahoma was positive for HPV, while results from Kansas sample 28 were not conclusive. All three samples from Oklahoma contained both TriMV and BYDV-PAV, and sample 24 also had BYDV-RPV. No antigens to WSMV or HPV could be detected in the second collection.

cDNA amplification and cloning. Viral specific primers amplified a TriMV CP fragment of $880 \mathrm{bp}$ in all of the samples except number 44 from Kansas (KS-44-Thomas), even though the sample was ELISA positive for TriMV. No variation in TriMV CP fragment size could be discerned from the agarose gels (data not shown). A WSMV CP amplicon of $800 \mathrm{bp}$ was obtained from samples TX-47-Ochiltree, OK-36-Kingfisher, OK-50-Texas, KS-28Smith, KS-44-Thomas, and KS-45-Meade and were not different in size. To deal with PCR error, five independent clones from each TriMV CP and WSMV CP amplification were sequenced and aligned to one another to derive a consensus sequence. Each collection contained single genotypes except samples TX-47-Ochiltree and OK-50-Texas, which contained two distinct genotypes of WSMV. Each genotype sequence from both TriMV and WSMV was deposited in GenBank (accession numbers GU724846GU724867) and given designations based on the state from which they were collected, sample number, and a two-letter designation for the county, i.e., OK-50-Tx.

Sequence comparisons. Fourteen consensus TriMV isolate sequences were aligned to one another using ClustalW and compared to the CP sequence of Kansas 06-123 (FJ263671, 3) and FJ669487 from Nebraska (25). Very little difference was seen between the isolates as evidenced by only 13 nucleotide changes across the $\mathrm{CP}$ and only three induced amino acid changes. Isolates TX-27-Ol and TX-4-Oc have a C-G change at position 31 that caused a Gln-Glu change. At position 46, a G-A nucleotide transition is present in four isolates, leading to an Ala-Thr amino acid switch. At nucleotide position 856, three isolates have a G-A transition that induces a Gly-Ser change in the protein. In relation to the full-length viral sequence (FJ263671), the nucleotide changes are $\mathrm{C} 9227 \mathrm{G}$,

Table 1. Isolate designations and descriptions of geographic locations for tissue samples used to isolate Triticum mosaic virus (TriMV) RNA ${ }^{\text {a }}$

\begin{tabular}{|c|c|c|c|c|c|c|c|}
\hline State & No. & County & WSMV & HPV & TriMV & BYDV PAV*b & BYDV RPV **b \\
\hline $\mathrm{TX}$ & 27 & Oldham & 1 & 0 & 1 & 0 & \\
\hline TX & 47 & Ochiltree & 1 & 0 & 1 & 0 & \\
\hline $\mathrm{TX}$ & 71 & Hale & 1 & 0 & 1 & 0 & 0 \\
\hline $\mathrm{OK}$ & 24 & Washington & 0 & 0 & 1 & 1 & 1 \\
\hline $\mathrm{OK}$ & 36 & Kingfisher & 1 & 0 & 1 & 1 & 0 \\
\hline $\mathrm{OK}$ & 50 & Texas & 1 & 1 & 1 & 1 & 0 \\
\hline KS & 28 & Smith & 1 & $1 ?$ & 1 & & \\
\hline KS & 44 & Thomas & 0 & 0 & 1 & & \\
\hline KS & 45 & Meade & 1 & 0 & 1 & & \\
\hline
\end{tabular}

a Tissue samples were tested for five viruses using enzyme-linked immunosorbent assay. " 1 " is positive and " 0 " is negative.

b *, Barley yellow dwarf virus strain PAV; **, Barley yellow dwarf virus strain RPV. 
G9242A, and G10052A, and amino acid changes are Q2830E, A2835T, and G3105S, respectively. KS-123-El originated from the same isolate that was used for full-length sequencing (3) and had experienced at least 20 passages prior to this study. Only one nucleotide difference was found between the isolate from 2006 and the isolate in 2008. Nucleotide changes in TriMV appeared to be random in relation to geographical location.

WSMV CP sequences were obtained from all of the samples that tested positive for WSMV. ClustalW alignments were made with the consensus sequence from all of the isolates. Comparisons of the cDNA indicate a high level of variation within WSMV that is co-infecting with TriMV. Overall, 65 positions had nucleotide changes when compared to the CP of Sydney81 (GenBank accession AF057533; 21). Matrix comparisons show that nucleotide identities between the isolates vary from 93 to $98.5 \%$ identity (data not shown). There was no specific genotype associated with TriMV coinfection.

\section{Discussion}

Wheat is grown in a monoculture across a wide area of the Great Plains of the United States, and volunteer growing in summer fallowed fields becomes a source of both fungal and viral pathogens. Recommended control strategies for viral diseases are the same: limit the source of inoculum, limit the increase and spread of the vector population, eradicate alternative hosts, and use late planting dates to avoid early mite establishment and reproduction. Both TriMV and WSMV occur in this region, and both are under similar constraints in terms of host range and vectoring (1).

WSMV has been well studied as a model for cereal viruses and is the type virus for the genus Tritimovirus. WSMV has a wide host range and is found in most wheat producing regions (4). Unlike most potyvirids, WSMV is not transmitted by aphids, but semiper- sistently by an eriophyid mite $(20,22)$. Genetic variation can be as high within isolates as variation among isolates (8) and is due to the viral polymerase being prone to mistakes. Sequence variation is high and can be seen within nine passages (7). WSMV CP genotypes in our study varied across the sampling region, and two samples had distinct genotypes within the same leaf sample. Our data show that WSMV possesses a high degree of genetic variation and confirms observations previously reported by Stenger et al. $(21,23)$.

Within the samples, TriMV exhibited low levels of genetic variation as compared to WSMV. There were only three CP nucleotide differences that resulted in amino acid changes in the 14 isolates sequenced. Two isolates of TriMV, collected several hundred miles from one another, have been completely sequenced $(3,25)$, and only 18 nucleotide differences were found, of which only four led to amino acid changes. The majority of polymorphic sites are found within P1 and HC-Pro. Complete sequencing of the isolates in this work might reveal greater variability in other regions of the virus genome. In RNA viruses, the replicase proteins are known for inaccuracy and generate variation needed for adaptation of new variants and species $(2,6)$. It would be expected for TriMV to follow suit. However, population structure is very dependent on bottlenecks and how new variants are selected. Although little is known about the ecology or epidemiology of TriMV, possible points of bottlenecks include host species, resistance within the host, and perhaps most importantly, vector transmission.

The lack of variation in TriMV CP sequence suggests the host is responsible for strong selection. The six isolates from Kansas in the second collection were sequenced after a minimum of 20 passages and showed very little sequence difference. If the replicase mutation rate of TriMV is similar to that of other potyvirids $(2,6)$, then a greater number of mutations should have been present. The

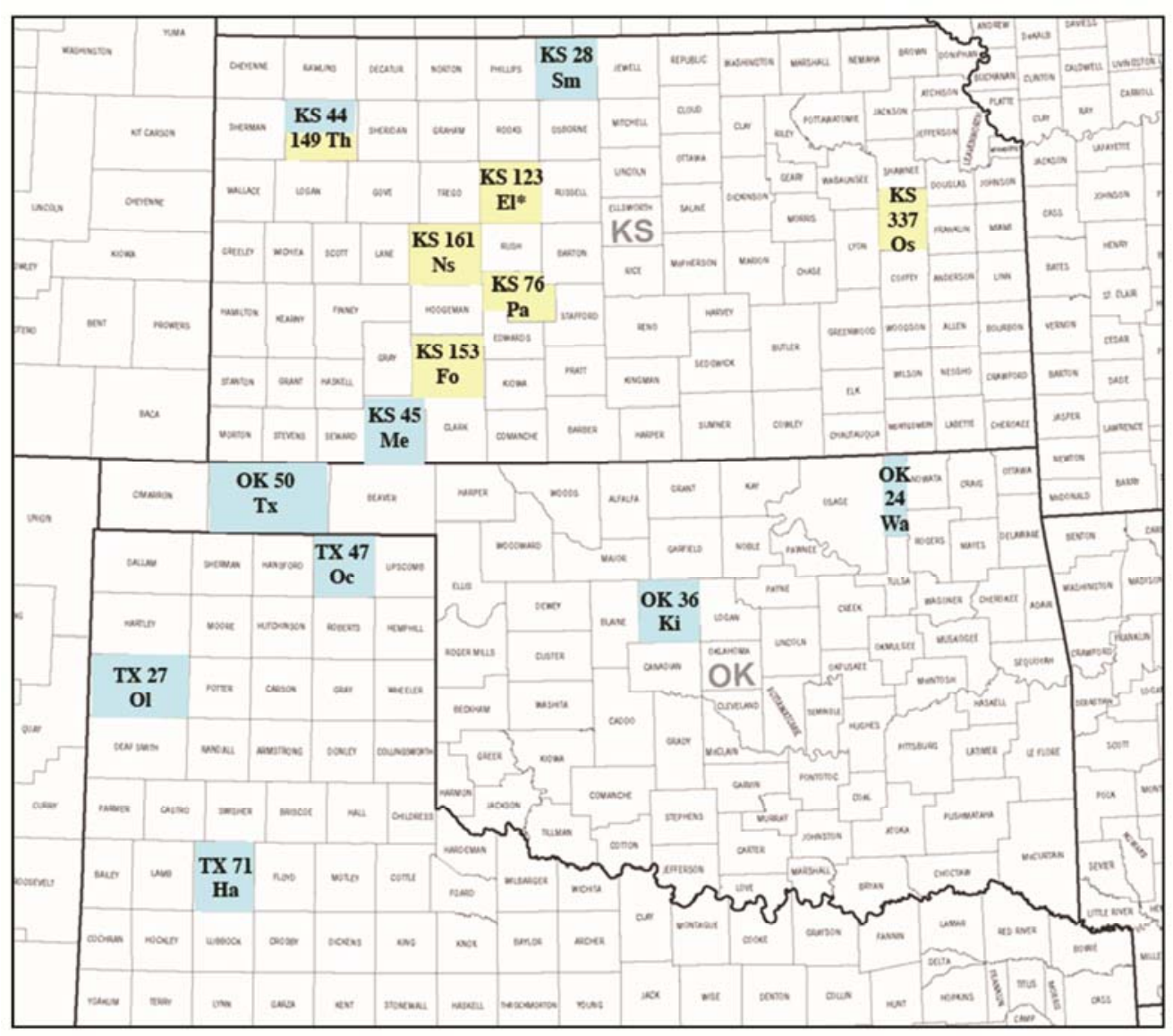

Fig. 1. Map locations from which samples were taken. Counties highlighted in blue represent locations of samples sent to the Texas AgriLife Research Center Plant Pathology Diagnostics Laboratory in Amarillo, TX in 2008. Counties in yellow are locations of samples taken in 2006 by D. Seifers and maintained in Tomahawk wheat. Designations are state, sample number, and a two-letter designation of the county sampled. ( ${ }^{*}$ ) Ellis County Kansas is where Triticum mosaic virus (TriMV) was first confirmed. 
$\mathrm{KS}-123-\mathrm{El}$ isolate did have one change, in comparison to the fulllength sequence of the same isolate (3). Contrasting this, WSMV variants were identifiable after nine wheat passages, and the majority of substitutions were in the NIa and CP of WSMV (7).

If a virus is well adapted to a host and there is no selection by resistance genes, numerous genotypes would be expected. WSMV has had no genetic resistance barriers until recently $(5,16)$. If TriMV was well adapted to wheat, the same level of variation would be expected; however, it is not. TriMV has possibly been horizontally transferred to wheat from another species and is currently undergoing adaptation. WSMV may have provided a cellular environment for initial TriMV establishment, and the plant is subjecting strong selection pressure for one genotype, as described in the founder effect $(4,6)$. The low number of amino acid variants indicates the virus is changing, but more variation would be expected.

In conclusion, the isolates of TriMV analyzed in this study exhibited very little variation. We suspect that TriMV is either a relatively new introduction into wheat or confined by a bottleneck in the host. The widespread geographic distribution of TriMV may favor the latter hypothesis. The lack of variation makes it difficult to identify a progenitor and recombination within variants. This work does demonstrate that real-time PCR primers designed for TriMV (9) will be useful in disease diagnostics.

\section{Acknowledgments}

We thank Drs. Dorith Rotenberg and Anna Whitfield for their comments in the preparation of this manuscript. This work was supported by USDA-ARS CRIS 5430-21000-006-00D, funding from the Great Plains Diagnostic Network, and the Texas AgriLife Cropping Systems Research Initiative.

\section{Literature Cited}

1. Burrows, M., Franc, G., Rush, C., Blunt, T., Ito, D., Kinzer, K., Olson, J., O'Mara, J., Price, J., Tande, C., Ziems, A., and Stack, J. 2009. Occurrence of viruses in wheat in the Great Plains region, 2008. Online. Plant Health Progress. doi:10.1094/PHP-2009-0706-01-RS.

2. Drake, J. W., and Holland, J. J. 1999. Mutation rates among RNA viruses. Proc. Natl. Acad. Sci. 96:13910-13913.

3. Fellers, J. P., Seifers, D., Ryba-White, M., and Martin, T. J. 2009. The complete genome sequence of Triticum mosaic virus, a new wheat-infecting virus of the High Plains. Arch Virol. 154:1511-1515.

4. French, R., and Stenger, D. C. 2003. Evolution of Wheat streak mosaic virus: Dynamics of population growth within plants may explain limited variation. Annu. Rev. Phytopathol. 41:199-214.

5. Friebe, B., Qi, L. L., Wilson, D. L., Chang, Z. J., Seifers, D. L., Martin, T. J., Fritz, A. K., and Gill, B. S. 2009. Wheat-Thinopyrum intermedium recombinants resistant to Wheat streak mosaic virus and Triticum mosaic virus. Crop Sci. 49:1221-1226.

6. Garcia-Arenal, F., Fraile, A., and Malpica, J. M. 2001. Variability and genetic structure of plant virus populations. Annu. Rev. Phytopathol. 39:157-186.

7. Hall, J. S., French, R., Hein, G. L., Morris, T. J., and Stenger, D. C. 2001. Three distinct mechanisms facilitate genetic isolation of sympatric Wheat streak mosaic virus lineages. Virology 282:230-236.

8. McNeil, J. E., French, R., Hein, G. L., Baenziger, P. S., and Eskridge, K. M. 1996. Characterization of genetic variability among natural populations of Wheat streak mosaic virus. Phytopathology 86:1222-1227.

9. Price, J. A., Smith, J., Simmons, A., Fellers, J., and Rush, C. M. 2010. Multiplex real-time RT-PCR for detection of Wheat streak mosaic virus and Triticum mosaic virus. J. Virol. Methods 165:198-201.

10. Seifers, D. L., Harvey, T. L., Kofoid, K. D., and Stegmeier, W. D. 1996. Natural infection of pearl millet and sorghum by Wheat streak mosaic virus in Kansas. Plant Dis. 80:179-185.

11. Seifers, D. L., Harvey, T. L., Martin, T. J., and Jensen, S. G. 1997. Identification of the wheat curl mite as the vector of the High Plains virus of corn and wheat. Plant Dis. 81:1161-1166.

12. Seifers, D. L., Martin, T. J., and Fellers, J. P. 2010. An experimental host range for Triticum mosaic virus. Plant Dis. 94:1125-1131.

13. Seifers, D. L., Martin, T. J., and Fellers, J. P. 2011. Occurrence and yield effects of wheat infected with Triticum mosaic virus. Plant Dis. 95:183-188.

14. Seifers, D. L., Martin, T. J., Harvey, T. L., Fellers, J. P., and Michaud, J. P. 2009. Identification of the wheat curl mite as the vector of Triticum mosaic virus. Plant Dis. 93:25-29.

15. Seifers, D. L., Martin, T. J., Harvey, T. L., Fellers, J. P., Stack, J. P., RybaWhite, M., Haber, S., Krokhin, O., Spicer, V., Lovat, N., Yamchuk, A., and Standing, K. G. 2008. Triticum mosaic virus: A new virus isolated from wheat in Kansas. Plant Dis. 92:808-817.

16. Seifers, D. L., Martin, T. J., Harvey, T. L., and Haber, S. 2007. Temperaturesensitive Wheat streak mosaic virus resistance acquired from KS03HW12 wheat. Plant Dis. 91:1029-1033.

17. Seifers, D. L., Martin, T. J., Harvey, T. L., Haber, S., and Haley, S. D. 2006. Temperature sensitivity and efficacy of Wheat streak mosaic virus resistance derived from C0960293. Plant Dis. 90:623-628.

18. Seifers, D. L., She, Y.-M., Harvey, T. L., Martin, T. J., Haber, S., Ens, W., Standing, K. G., Louie, R., and Gordon, D. T. 2004. Biological and molecular variability among High Plains virus isolates. Plant Dis. 88:824-829.

19. Skare, J. M., Wijkamp, I., Rezende, J. A. M., Kitajima, E. W., Park, J.-W., Desvoyes, B., Rush, C., Michels, G., Scholthof, K.-B., and Scholthof, H. B 2006. A new eriophyid mite-borne membrane-enveloped virus-like complex isolated from plants. Virology 347:343-353.

20. Slykhuis, J. T. 1955. Aceria tulipae Keifer (Acarina Eriophyidae) in relation to the spread of Wheat streak mosaic. Phytopathology 45:116-128.

21. Stenger, D. C., Hall, J. S., Choi, I.-R., and French, R. 1998. Phylogenetic relationships within the family Potyviridae: Wheat Streak Mosaic Virus and Brome Streak Mosaic Virus are not members of the genus Rymovirus. Phytopathology 88:782-787.

22. Stenger, D. C., Hein, G. L., and French, R. 2006. Nested deletion analysis of Wheat streak mosaic virus HC-Pro: Mapping of domains affecting polyprotein processing and eriophyid mite transmission. Virololgy 350:465-474.

23. Stenger, D. C., Seifers, D. L. and French, R. 2002. Patterns of polymorphism in Wheat streak mosaic virus: Sequence space explored by a clade of closely related viral genotypes rivals that between the most divergent strains. Virology 302:58-70.

24. Tatineni, S., Graybosch, R. A., Hein, G. L., Wegulo, S. N., and French, R. 2010. Wheat cultivar-specific disease synergism and alteration of virus accumulation during co-infection with Wheat streak mosaic virus and Triticum mosaic virus. Phytopathology 100:230-238.

25. Tatineni, S., Ziems, A. D., Wegulo, S. N., and French, R. 2009. Triticum mosaic virus: A distinct member of the family Potyviridae with an unusually long leader sequence. Phytopathology 99:943-950. 